\title{
A revision of the genus Geitlerinema and a description of the genus Anagnostidinema gen. nov. (Oscillatoriophycidae, Cyanobacteria)
}

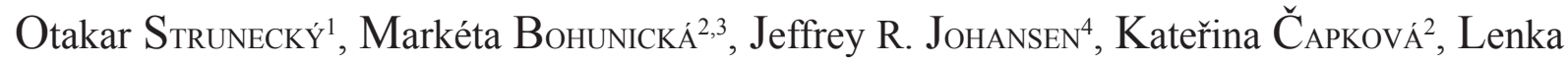 \\ RaAbová ${ }^{5}$, Petr Dvořák ${ }^{6} \&$ Jiří KomÁReK ${ }^{2}$
}

\author{
'Institute of Aquaculture, Faculty of Fisheries and Protection of Waters, CENAKVA, University of South Bohe- \\ mia, Husova 458, CZ-370 05, České Budějovice, Czech Republic \\ ${ }^{2}$ Centre for Phycology, Institute of Botany of the Czech Academy of Sciences, Dukelská 135, CZ-379 82, True- \\ boň, Czech Republic \\ ${ }^{3}$ Research and Breeding Institute of Pomology, Holovousy Ltd., Holovousy 129, CZ-508 01, Hořice, Czech \\ Republic \\ ${ }^{4}$ Department of Biology, John Carroll University, University Heights, OH 44118, Cleveland, USA \\ ${ }^{5}$ Department of Biology, University of Ss. Cyril and Methodius, J. Herdu 2, Trnava, SK-917 01, Slovak Republic \\ ${ }^{6}$ Department of Botany, Faculty of Science, Palacký University Olomouc, Šlechtitelu 27, CZ-783 71, Olomouc, \\ Czech Republic
}

\begin{abstract}
The simple filamentous cyanobacterial genus Geitlerinema is heterogeneous. At least two distinct phylogenetic clades can be derived from the set of most common freshwater Geitlerinema species. Our revision is based on the original description of the type species G. splendidum aka Oscillatoria spendida and on molecular sequencing of morphologically relevant strains. The revised Geitlerinema contains only one species according to morphological similarity with its original description. Consequently, the majority of other freshwater species inferred from molecular sequencing of 16S rRNA gene and 16S-23S ITS analysis (related both genetically and morphologically to G. pseudacutissimum) must be classified as a special taxon on the generic level. The name Anagnostidinema is proposed for this genus, which was selected in memory of the prominent late cyanobacterial specialist Konstantinos Anagnostidis. The genetic position, short review and characteristics of the newly defined genus Anagnostidinema is presented in this paper. The taxonomy of the rest of species (including the marine taxa), which are currently unable to be classified taxonomically with certainty, remain to be resolved in future studies.
\end{abstract}

Key words: 16S rRNA; Anagnostidinema; Cyanobacteria; ecology; Geitlerinema; 16S-23S rRNA ITS; molecular sequencing; morphology; new genus

\begin{abstract}
Abbreviations: ITS, Internal Transcribed Spacer situated between 16S and 23S rRNA; CCALA, Culture Collection of Autotrophic Organisms, Třeboň, Czech Republic; CBFS, České Budějovice Faculty of Science Herbarium; PCC, Pasteur Culture Collection of Cyanobacteria, Paris, France; SAG, Culture Collection of Algae at the University of Göttingen, Germany
\end{abstract}

\section{INTRODUCTION}

The thin simple filamentous cyanobacteria from the orders Synechococcales and Oscillatoriales have very low morphological variability. Historical reliance on only few markers, e.g., lack of visible sheath or its pigmentation, filament tapering, length of cells, etc., led to the erection of genera that subsequently have been demonstrated to be polyphyletic according to $16 \mathrm{~S}$ rDNA sequence analyses (e.g. KomÁreK \& Anagnos- tidis 2005; Perkerson et al. 2011; Chatchawan et al. 2012; KOMÁREK et al. 2014). As a consequence of findings based on the 16S rRNA gene, re-evaluation of the corresponding cytomorphological and ecological features is necessary.

The various species of Geitlerinema were classified in the past mainly into the genus Oscillatoria in respect to the absence of all types of derived cells (heterocytes etc.) and lack of visible sheaths (e.g., GomONT 1892; GeitLer 1956). The genus Geitlerinema was separated from the LPP-B "Oscillatorian" group sensu 
RipPKA et al. (1979) by ANAGnostidis (1989). The main diacritical features of this genus that differentiate it from other similar simple filamentous genera are thin, cylindrical trichomes $(<6 \mu \mathrm{m})$, intense gliding motility with oscillation and rotation and lack of sheath material. The relatively thin trichomes with various types of attenuation and bending of terminal cells are never firmly attached to any substrate. The position of thylakoids in cells is in principle parietal, but with numerous irregularities and specificities.

The type species of Geitlerinema is G. splendidum (Greville ex Gomont) Anagnostidis (AnAgnosTIDIS 1989), which possesses apical cells strikingly attenuated and hooked (when fully developed), and more or less spherically capitate at the ends. The trichomes are thin (1.8-3 $\mu \mathrm{m}$ wide), intensely motile, gliding with oscillation and rotation, not constricted at the cross-walls, attenuated towards the ends. Cells are 2-4 times longer than wide, sometimes with prominent cyanophycin granules near the cross-walls (KOMÁREK \& AnAGNOSTIDIS 2005). The type locality of the taxon is a freshwater water tube in the Botanical Garden at Edinburgh, Scotland.

Recent phylogenetic analyses demonstrated that the genus Geitlerinema in its current concept is polyphyletic (MARGHERI et al. 2003; STRINGFELLOW et al. 2007; Bittencourt-Oliveira et al. 2009; Perkerson et al. 2010) and revision of the genus is required. The combined molecular and morphological description of a characteristic representative of the type species, G. splendidum, has not yet been published, although images and phylogeny were documented in HAŠLER et al. (2012). In this study, we describe both phylogenetic and cytomorphological features of this species. Using a total-evidence approach we characterize and taxonomically transfer the former Geitlerinema species $G$. pseudacutissimum and G. amphibium into Anagnostidinema gen. nov. We also transfer nine additional Geitlerinema species into Anagnostidinema based on morphological data. Some Geitlerinema, such as the marine species, likely do not belong to either Geitlerinema or Anagnostidinema, and consequently we regard this study as only the first step in revision of the genus; we anticipate further fragmentation in the future.

\section{Material ANd Methods}

The strains in this study were isolated from freshwaters and soils, sampled in various localities worldwide. A few strains were obtained from the CCALA Culture Collection of $\mathrm{Au}-$ totrophic Organisms (Třeboň, Czech Republic). Recently obtained strains designated as morphologically confirmed reference strains in this study were newly included into this collection. Accession numbers and origin of the strains are provided in Table 1 . The strains were maintained on agar solidified Z8 medium (CARMichael 1986) at $18{ }^{\circ} \mathrm{C}$ and dim light in $12 / 12$ photoperiod.
Morphological Evaluation and Ultrastructure. Cultured strains were examined by both light microscopy (LM) and transmission electron microscopy (TEM). Light microscopy observations were performed using an Olympus BX 51 light microscope equipped with Nomarski DIC optics and an Olympus DP71 digital camera.

For TEM, young cultures in exponential growth phase were prepared by fixation in glutaraldehyde: $3 \%(\mathrm{w} / \mathrm{v})$

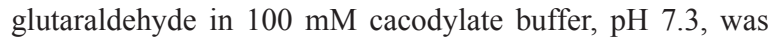
applied for 3 hours at $4{ }^{\circ} \mathrm{C}$, followed by postfixation by $1 \%$ $(w / v)$ osmium tetroxide in the same buffer for 2 hours at $4{ }^{\circ} \mathrm{C}$. The material was then washed with the buffer overnight at $4{ }^{\circ} \mathrm{C}$. Thereafter, it was instilled in $2 \%(\mathrm{w} / \mathrm{v})$ agar and, within it, dehydrated by a series of ethanol at gradually increasing concentrations. Following the dehydration, it was infiltrated with metacrylate LR White - in ethanol 1:1 for 30 $\mathrm{min}$, then in ethanol 2:1 for $60 \mathrm{~min}$, in ethanol 3:1 for 2 hours and, finally, in LR White pure at $4{ }^{\circ} \mathrm{C}$ for 3 days. Afterwards, it was encapsulated and polymerized by UV rays at $4{ }^{\circ} \mathrm{C}$ for 3 days. The material was then cut to ultrathin sections by a Reichert-Jung ultramicrotome Ultracut E. All the final sections were placed on supporting grids and contrasted by $2.5 \%$ $(w / v)$ uranyl acetate. The final sections were photographed at various magnifications using a digital transmission electron microscope JEOL JEM-1010.

16S rRNA Gene Sequencing and Phylogenetic Analysis. Total genomic DNA was isolated following the modified xanthogenate-SDS buffer extraction protocol with addition of 3\% PVPP and PEG- $\mathrm{MgCl}_{2}$ precipitation (MAREŠ et al. 2013). A section of the rRNA operon containing the partial 16S rRNA gene and the 16S-23S intergenetic spacer (ITS) was amplified using the primers 359F (5'-GGG GAA TYT TCC GCA ATG GG-3'; NüBEL et al. 1997), and 23S30R (5'-CTT CGC CTC TGT GTG CCT AGG T-3'; Wilmotte et al. 1993). The template DNA was mixed with 5 pmol of each primer in $50 \mu \mathrm{l}$ of commercial PCR mix with Taq polymerase (Plain PP Master Mix, Top Bio, Czech Republic). The amplification was run using the following settings: a starting denaturation step $\left(94{ }^{\circ} \mathrm{C}, 5 \mathrm{~min}\right) ; 40$ cycles of $30 \mathrm{~s}$ at $94{ }^{\circ} \mathrm{C}$, $30 \mathrm{~s}$ at $53{ }^{\circ} \mathrm{C}$, and 3 minutes at $72{ }^{\circ} \mathrm{C}$; final extension for 7 minutes at $72{ }^{\circ} \mathrm{C}$ and cooling to $4{ }^{\circ} \mathrm{C}$. The success of the PCR was verified by running a sub-sample on a $1.5 \%$ agarose gel stained with ethidium bromide. Sequencing was done by Macrogen (Amsterdam, Netherlands) using primers 359F, 23S30R, 1492R (5'-TAC GGY TAC CTT GTT ACG ACT T-3') and 810R (5'-GTT ATG GTC CAG CAA AGC GCC TTC GCC A-3') (STRUNECKY et al. 2014).

Sequences of the 16S rRNA gene were aligned in MAFFT (mafft.cbrc.jp; КАТОH \& ТОН 2010). Minor changes were done manually with BioEdit 7.0.1 (HaLl 1999). A fragment of $\sim 1081 \mathrm{nt}$ was used for the phylogenetic analysis of the 16S rDNA (starting at E. coli ATCC $1177516 \mathrm{~S}$ rRNA residue 302). The obtained sequences were blasted against GenBank and sequences of similar organisms were added into the alignment together with other cyanobacterial strains previously published as Geitlerinema. The rest of the sequences of cyanobacterial strains were added as outgroup taxa for a congruent phylogeny (cf. MARES et al. 2013; BoHUNICKÁ et al. 2015).

The phylogenetic tree topology was based on Bayesian inference analysis computed in MrBayes 3.2.2 (RonQuisT \& HuelsENBECK 2003). For the Bayesian analysis, four runs of four Markov chains were calculated for 12 million generations, sampling every 1,000 generations. The initial $25 \%$ 


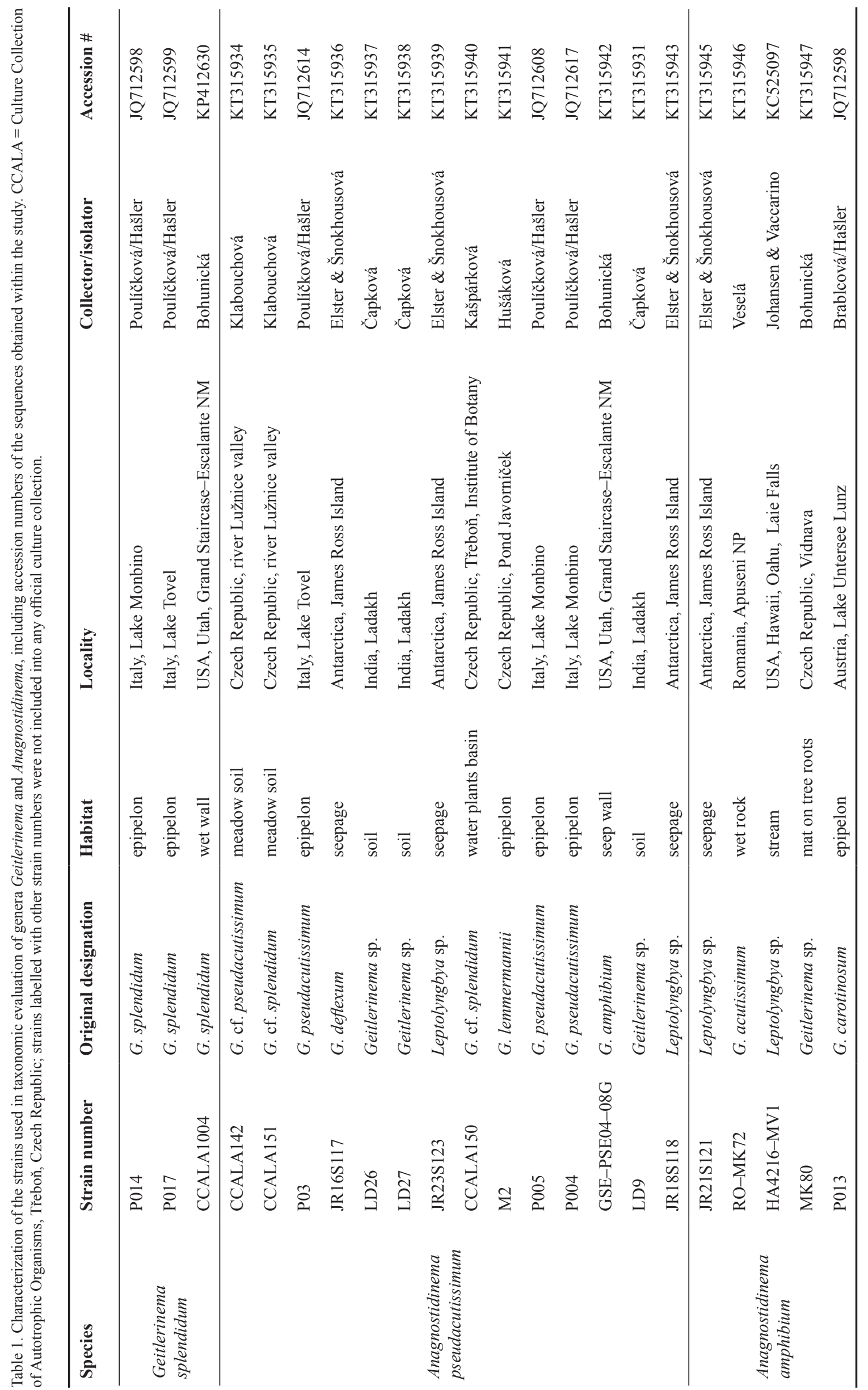


of generated trees were discarded as burn-in. The tree was validated by maximum likelihood method in RAxML 7.0.4 (STAMATAKIs 2006) under a GTR model with 1,000 bootstrap repetitions and neighbor joining under maximum composite likelihood model with uniform rates among sites in MEGA 6.06 (TAMURA et al. 2011) with 1,000 bootstrap repetitions. The secondary structures of different ITS regions (D1-D1' helix and Box-B helix) were predicted with the Mfold web server version 3.2 (ZUKER 2003) with temperature set to default conditions $\left(37^{\circ} \mathrm{C}\right)$ and draw mode at untangle with loop fix. Secondary structures were then drawn in Adobe Illustrator $(\mathrm{CS}-3)$.

\section{ReSUlTS}

A total of 23 strains were studied (Table 1). Morphological evaluation of freshwater and soil strains confirmed taxonomical designation into the genus Geitlerinema according to KoMÁREK \& ANAGNOSTIDIS (2005). The strains P014, P017, CCALA 1004 morphologically matched the typical $G$. splendidum sensu stricto. Other strains were originally classified as $G$. pseudacutissimum, G. amphibium, G. carotinosum, or Geitlerinema sp. The sequence data of the $16 \mathrm{~S}$ rRNA gene (for accession numbers see Table 1) grouped the strains into three major clades. One clade was formed by three morphologically distinct strains of G. splendidum sensu stricto (Figs 1, 2A-F, 3A-D). The rest of the freshwater strains clustered into another clade that was both phylogenetically and morphologically distinct, and which we here designate as Anagnostidinema gen. nov. (Figs 1, 2G-V, 3E-I). A third clade of marine Geitlerinema strains was situated near to Planktothrix agardhii and was phylogenetically very distant from either freshwater clade (Fig. 1), which is consistent with previous reports (PERKERSON et al. 2010). As these species are clearly not in Geitlerinema sensu stricto or Anagnostidinema gen. nov., they will not be treated further here.

Examination of sequence identities of the strains of interest based on their 16S rRNA gene sequence clearly supported the separation of the three clades. The gene identity of $G$. splendidum representatives was internally high ( $>97 \%)$, but was lower than $93 \%$ in comparison to the species formerly classified in Geitlerinema that we now assign to Anagnostidinema. The members of the marine Geitlerinema clade were less than $89 \%$ identical to the two freshwater clades (Table 2). Anagnostidinema gen. nov. formed an isolated clade with $16 \mathrm{~S}$ rRNA sequence identity always less than $93 \%$ to representatives of adjacent clades (Fig. 1; Table 2). Within Anagnostidinema, at least two species were evident (Fig. 1). One group of strains was highly morphologically consistent with the original description of G. pseudacutissimum (Figs $2 \mathrm{G}-\mathrm{N}, 3 \mathrm{E}-\mathrm{I}$ ), and we place all of these strains into Anagnostidinema pseudacutissimum comb. nov., regardless of original strain designation (Table 1). The other group of strains was morphologically consistent with either G. amphibium or G. carotinosum (Figs 2O-V), two species whose separation has been questioned by other workers. We place almost all of these strains into Anagnostidinema amphibium comb. nova in this paper, although we recognize that further study may show this lineage has genetically diverse members (i.e. cryptic species, probably with $A$. carotinosum).

The cellular ultrastructure of Geitlerinema and Anagnostidinema is similar. In both taxa thylakoids are irregularly parietal, with 4-6 thylakoid layers cylindrically and peripherally positioned along the cell walls (Fig. 3). In G. splendidum, thylakoids are characteristically wavy and sometimes separated from a strictly parietal position (Figs 3A-D). Thylakoids constitute the majority of the cytoplasm, with granules visible within the centroplasm.

Examination of the 16S-23S ITS region, which was found only as a single operon per studied strain according to raw sequences, showed evidence of deep genetic separation of Geitlerinema and Anagnostidine$m a$ (Fig. 4; Table S1). The lengths of the domains of the ITS region were remarkably consistent within both species and genera. Geitlerinema splendidum was notably longer in sequence length for the D1-D1' helix, spacer with D2 and D3, V2, and spacer to end of BoxB, while its D4 to V3 domain and V3 helix were both smaller. The differences in lengths between $A$. pseudacutissimum and $A$. amphibium were less marked, but fairly consistent within species grouping (Table S1).

Secondary structure of the $16 \mathrm{~S}-23 \mathrm{~S}$ ITS region was also congruent with the morphological and phylogenetic evidence. G. splendidum had markedly different D1-D1', boxB, and V3 helices in comparison to the two Anagnostidinema species (Fig. 4). Specifically, the D1-D1' helix of Geitlerinema (Figs 4F,G) had a short basal stem of only $4 \mathrm{bp}$, a large bilateral bulge only $2 \mathrm{bp}$ from the basal unilateral bulge, and a large terminal loop (15-16 nt as compared to $4 \mathrm{nt}$ in Anagnostidinema; Figs 4A-E). The BoxB helices in Geitlerinema were characterized by a basal mismatch that was C:AA rather than A:CC (Figs $4 \mathrm{H}-\mathrm{N}$ ). Finally, the V3 helices in Geitlerinema were highly divergent from those in Anagnostidinema in both sequence and structure (Figs 4O-T).

Within Anagnostidinema, the differences in secondary structures of the two species were striking, and their separation was well supported. The structures within $A$. pseudacutissimum were more consistent between strains than in A. amphibium (Figs 4A-B, $\mathrm{H}-\mathrm{I}, \mathrm{O}-\mathrm{P})$. The structures were sufficiently divergent within A. amphibium to conclude that cryptic diversity may exist in this cluster (Figs $4 \mathrm{C}-\mathrm{E}, \mathrm{J}-\mathrm{L}$ ), and that with further study, more species may be recognized in the clade. More sequences of existing taxa are needed, as the diversity may have already been taxonomically circumscribed. In particular, $A$. carotinosum is similar 
to A. amphibium and may be represented in our phylogeny together with $A$. amphibium (they differ only slightly in dimensions and by the composition of granules in cells). We consider resolution and combination of cryptic species within Anagnostidinema to be beyond the scope of this study.

From the combined molecular analyses and congruent detailed morphology, it is evident that Geitlerinema sensu stricto currently includes only the type species, G. splendidum. The other species previously assigned to it are, based on morphology and our limited molecular study, in other genera. At this time we more narrowly circumscribe the genus Geitlerinema, give a species description based on the strains we used for sequencing, and describe Anagnostidinema, as well as transfer the majority of noncapitate species to the latter genus. Sequenced strains assigned to Geitlerinema that fall outside of both G. splendidum and Anagnostidinema clades require further study and eventual taxonomic circumscription. Two previously described taxa, G. apolloniae Anagnostidis and G. sandbergii (Skuja) Anagnostidis, most probably do not belong to either genus based on their very divergent morphology.

The holotype specimen of Geitlerinema splendidum probably resides in the Herbarium Greville at the Royal Botanic Garden Edinburgh, Scotland, but have not been catalogized yet. Oscillatoria splendida was originally collected in tubs of water in a stove in the Botanic Garden in Edinburgh in 1824. This genus and species were correctly typified and validly published under the ICN and are well established in a recent work (KomÁREK \& ANAGNOSTIDIS 2005).

We have studied and sequenced the strains CCALA 1004, P014, and P017 (HAŠLER et al. 2012), which all fully correspond to the description of $G$. splendidum (KoMÁReK \& ANAGNOSTIDIs 2005, p. 129, fig. 137). The original description and illustrations of Oscillatoria splendida were also examined (GomonT 1892, p. 224, plate 7 , figs. 7,8 ) and found to be in strict agreement with later circumscriptions of the species. This species is easily recognized by its translucent trichomes which exhibit rapid gliding as well as very distinctive capitate end cells. Below we characterize our strain material to document the morphology of our sequenced strains. The European strains P014 and P017 were unfortunately lost after morphological characterization and sequencing (HAŠLER et al. 2012). We are consequently proposing North American CCALA 1004 be considered a reference strain until European material again becomes available, recognizing that this reference strain has no nomenclatural standing in either nomenclatural code governing cyanobacteria. Because the holotype material is not accessible and supposed to be deformed after nearly 200 years of existing in a dried state in a herbarium, we consider it to be "demonstrably ambiguous and cannot be critically identified for purposes of the precise application of the name to a taxon" (Article 9.20, ICN), and consequently establish an unambiguous type based upon dried material deposited in the CBFS Herbarium in České Budějovice, Czech Republic. That material (CBFS A-056) is based on the strain CCALA 1004, which was chosen because it was the only taxonomically confirmed strain present in an actively curated public culture collection, which can be obtained by other workers for molecular or biochemical study.

\section{Geitlerinema (Anagnostidis et KomÁrek) Anagnosti- DIS 1989}

Description: Thallus thin, delicate, mostly bright bluegreen, diffluent, sometimes fascicle-like, usually forming thin mats; occasionally isolated trichomes. Sheaths absent. Trichomes \pm parallel-arranged, cylindrical, straight, slightly flexuous, not constricted at the crosswalls, bent and spherically capitate at the ends, motile, with intense gliding in the direction of the longitudinal axis, sometimes accompanied by a distinctive rotation, 1.5-3 $\mu \mathrm{m}$ wide. Cells rarely short, up to $2-4(6) \times$ longer than wide, $3.5-8 \mu \mathrm{m}$ long, pale grayish, blue-green or bright blue-green, without evident chromatoplasma or centroplasma, sometimes with translucent cyanophycin granules at the cross-walls, without aerotopes. Apical cells in developed trichomes bent or/and apparently spherical-capitate. Thylakoids concentrically arranged, peripheral and more or less parallel to the longitudinal cell walls, forming a wavy concentric inner cylinder. Centroplasma includes droplets of polyphosphates, starch and carboxysomes (Fig. 3, A-D). The main diacritic features are trichomes lacking sheaths and particularly the morphology of the end cells that are bent, spherically capitate, and elongated up to $15 \mu \mathrm{m}$ when mature. Reproduction by disintegration of trichomes into motile hormogonia, without necridic cells.

Habitat: The taxon occurs commonly in shallow stagnant freshwaters, thermal water and wet rocks.

Iconotype: Geitlerinema splendidum (Greville ex Gomont) ANAGNostidis 1989, based on Oscillatoria splendida Greville ex Gomont, Annales des Sciences Naturelles, Botanique, Série 7 16:224, pl. VII: figs 7, 8, 1892.

\section{Geitlerinema splendidum (Greville ex Gomont) Anagnostidis 1989 (Figs 2A-F, 3A-D)}

Colony (thallus) spreading, with bundles of filaments, sometimes forming coils, bright green to blue-green, olive when old, not mucilaginous. Trichomes up to 1 $\mathrm{mm}$ long, intensely motile, slightly bent and entangled, slightly constricted at the distinct cross-walls, 2-2.3 $\mu \mathrm{m}$ wide. Cells 2-4× longer than wide, pale grayish, blue-green or bright blue-green, without evident chromatoplasma or centroplasma, with translucent cyanophycin granules at the cross-walls, (3)3.5-8 $\mu \mathrm{m}$ long. The main diacritic feature is morphology of trichomes without sheaths and particularly the shape of the end cells, which are in developed stages attenuated and 
elongated, narrowed, bent, spherically capitate, up to $15 \mu \mathrm{m}$ long.

Habitat: The taxon occurs commonly in shallow stagnant freshwaters and wet rocks.

Epitype: dry material CBFS A-056 is based on strain: Geitlerinema splendidum CCALA 1004.

\section{Species excluded from Geitlerinema according to morphologic evaluation}

\section{G. apolloniae Anagnostidis}

This species has trichomes too wide (up to $6.5 \mu \mathrm{m}$ ) to be considered Geitlerinema, as well as cells that are shorter than wide to isodiametric. It requires revision, and at this point in time without sequence data or ultrastructure it cannot be reliably assigned to any genus.

\section{G. sandbergii Skuja}

This species was described from soil in Sweden. It is also too wide $(5-6.5 \mu \mathrm{m})$ and has cells shorter than wide to isodiametric. It is also calyptrate. It conforms in both morphology and ecology to Microcoleus vaginatus, and we consider it to be a later synonym of that species.

\section{Anagnostidinema Strunecký, Bohunická, Johansen et Komárek gen. nov.}

Description: Colonies spreading, green to blue-green, mucilaginous, amorphous. Sheaths absent. Trichomes thin, mostly bright blue-green (aquamarine), usually straight or slightly bent, dispersed evenly and loosely without mat formation, unconstricted or only indistinctly constricted at cross-walls. Sheaths absent. Trichomes cylindrical, straight, not capitate, motile with intense gliding in the direction of the longitudinal axis, sometimes accompanied by bending and distinctive rotation, $1-3 \mu \mathrm{m}$ wide. Cells usually 2-4 longer than wide, 4-8 $\mu \mathrm{m}$ long, sometimes with visible peripheral chromatoplasma, sometimes with evident carotenoid granules, without aerotopes, after division growing to the size of the mother cells before the next cell division. Apical cells in developed trichomes bent, narrowed and pointed-rounded, never calyptrate or capitate. Thylakoids parietal, with triangle or rhombic organization in transversal section. Reproduction by disintegration of trichomes in hormogonia without necridic cells.

Etymology: named in memory of the prominent late cyanobacterial specialist Konstantinos Anagnostidis, combined with the Greek word nema - a cable.

Type species: Anagnostidinema pseudacutissimum (Geitler) comb. nov.

Anagnostidinema morphologically differs from Geitlerinema in the absence of capitate apical cells, phylogenetic placement, and in secondary structure of conserved domains of the $16 \mathrm{~S}-23 \mathrm{~S}$ ITS region.

Anagnostidinema pseudacutissimum (GeITLER) Strunecký, Bohunická, Johansen et Komárek comb. nov. (Figs 2G-N, 3E-I)

Basionym: Oscillatoria pseudacutissima GeITLER, Österr. Bot. Zeitschr. 103(2-3): 343, pl. 1, figs. c, d, 1956.

Synonym: Phormidium pseudacutissimum (GeItler) Anagnostidis et KomÁreK, Arch. Hydrobiol. Suppl./Algol. Stud. 50-53: 404, 1988; Geitlerinema pseudacutissimum (Geitler) Anagnostidis, Plant. Syst. Evol. 164: 43, 1989; (Figs 2G-N, 3E-I).

Description: Colonies (thallus) spreading, mounded, in cultures penetrating the agar, with rings of trichomes visible as minute coils in the colony, blue-green, dark green, pale olive-green to orange. Sheaths absent. Trichomes thin, bright blue-green, usually straight or slightly bent, dispersed evenly and loosely without mat formation, unconstricted or only indistinctly constricted at the cross-walls, 1.3-2.2 $\mu \mathrm{m}$ wide, slightly attenuated and bent at the ends, motile with gliding motility. Sheaths absent. Cells pale olive-green to bright blue-green, sometimes with orange granules at the cross-walls, 2-4× longer than wide, 4-8 $\mu \mathrm{m}$ long. Apical cells (developed) cylindrical rounded and elongated, conical, sometimes bent or hooked, never calyptrate. Necridic cells not observed. Thylakoids parietal with generally straight four to five layers of thylakoid membranes. Thylakoids in transversal section with triangle or rhombic organization (Fig. 3G). Numerous polyphosphates of variable size were found, mainly at the peripheral part of the cells (e.g., Fig. 3I).

Habitat: Freshwater, in littoral of lakes, periodically flooded meadows, thermal springs, isolated pools.

Holotype: O. pseudacutissima specified by GeITLER (1956) in the original publication as an exsicate in the Herbarium of the Botanischen Institut der Universität Wien. Due to the ambiguous nature of dried material, we here designate an epitype.

Epitype: dry material CBFS A-057 is based on the strain CCALA150. Other strains available for comparison which we consider also to be this species are CCALA150 and CCALA 151.

Anagnostidinema amphibium (AgARDH ex GOMONT) STrunecký, Bohunická, Johansen et Komárek comb. nov. (Figs 2O-V)

Basionym: Oscillatoria amphibia Agardh ex Gomont, Ann. Sci. Nat.-Bot. 16: 221, pl. VII, fig. 6, 1892.

Synonym: Phormidium amphibium (Agardh ex Gomont) AnagnosTIDIs et KomÁreK, Arch. Hydrobiol. Suppl./Algol. Stud. 50-53: 404, 1988; incl. Oscillatoria amphibia f. contorta G.S. WEST, J. Bot. 67: 243, 1909a ; Oscillatoria amphibia f. circinata ANAGNOstidis, Ereynai Kyanoph. Therm. Ellados, p. 233, 1961; Geitlerinema amphibium (Agardh ex Gomont) Anagnostidis, Plant. Syst. Evol. 164: 38, 1989).

Description: Colonies (thallus) spreading, mounded, in cultures penetrating the agar, expanding, with rings of trichomes visible as minute coils in the colony, dark 


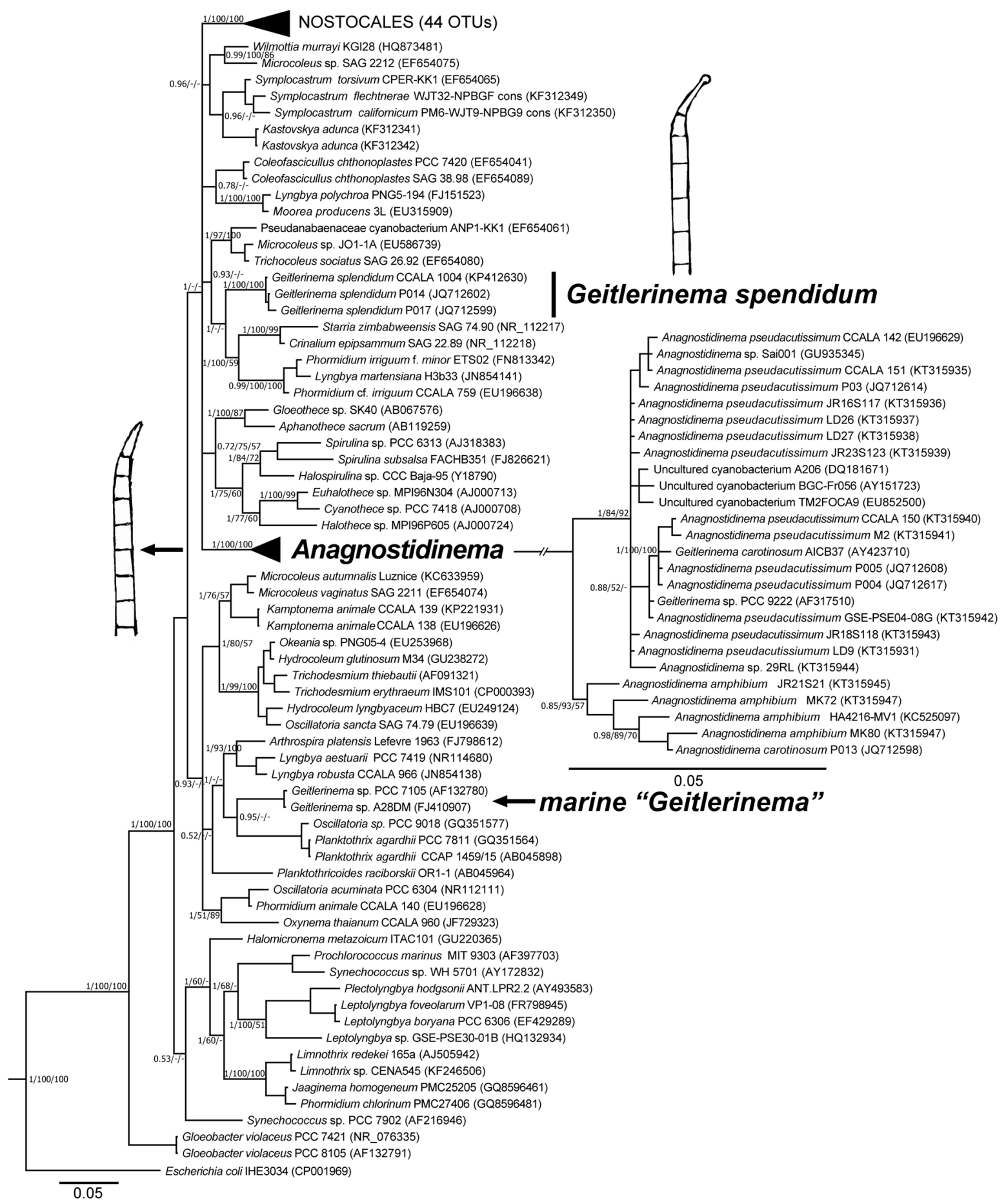

Fig. 1. Phylogenetic analysis based on 126 sequences of the 16S rRNA gene showing position of the genera Geitlerinema and Anagnostidine$m a .1,081$ bp of the $16 \mathrm{~S}$ rRNA gene (starting at $E$. coli ATCC $1177516 \mathrm{~S}$ rRNA residue 302) were used for phylogenetic comparisons. Branch support values are shown as Bayesian posterior probability, Maximum Likelihood, and Neighbor Joining bootstrap values, respectively. Values smaller than 0.5 or 50 percent are not shown.

green, blue-green, pale olive-green to orange. Trichomes usually straight or slightly curved and long, \pm parallel arranged, frequently also screw-like coiled or circled, motile with gliding motility (oscillation or rotation), forming thin mats or dispersed evenly and loosely without mat formation, unconstricted at the cross-walls, (1)1.5-3(4) $\mu \mathrm{m}$ wide, slightly attenuated and bent at the ends. Cells pale olive-green to blue- green, sometimes greenish to yellow-green, without evident chromatoplasma or centroplasma, often with orange granules at the cross-walls, $2-3 \times$, sometimes up to 4 times longer than wide, $3-9 \mu \mathrm{m}$ long (Figs $2 \mathrm{O}-\mathrm{V}$ ). Thylakoids in cross-section concentrically arranged, peripheral, parallel oriented, in transverse section with triangular orientation. Apical cells (in natural material) cylindrically rounded or elongated and 
Table 2. Nucleotide similarity of 16S rRNA gene of Geitlerinema and Anagnostidinema with phylogenetically relevant strains. The values are given in percentage of similarity of $1,081 \mathrm{bp}$ of the $16 \mathrm{~S}$ rRNA gene (starting at E. coli ATCC $1177516 \mathrm{~S}$ rRNA residue 302).

\begin{tabular}{|c|c|c|c|c|c|c|c|c|c|c|c|c|}
\hline & Strain name & 1 & 2 & 3 & 4 & 5 & 6 & 7 & 8 & 9 & 10 & 11 \\
\hline 1 & Geitlerinema splendidum CCALA 1004 & & & & & & & & & & & \\
\hline 2 & Crinalium epipsammum SAG 22.89 & 93 & & & & & & & & & & \\
\hline 3 & Starria zimbabweensis SAG 74.90 & 91 & 97 & & & & & & & & & \\
\hline 4 & Wilmottia murrayi KGI28 & 92 & 93 & 91 & & & & & & & & \\
\hline 5 & Trichocoleus sociatus SAG 26.92 & 93 & 93 & 90 & 93 & & & & & & & \\
\hline 6 & Coleofasciculus chthonoplastes SAG 38.89 & 91 & 91 & 90 & 93 & 92 & & & & & & \\
\hline 7 & Kamptonema animale CCALA 138 & 92 & 93 & 91 & 93 & 93 & 93 & & & & & \\
\hline 8 & Geitlerinema sp. PCC 7105 & 89 & 88 & 88 & 89 & 89 & 91 & 91 & & & & \\
\hline 9 & Limnothrix redekei 165 a & 88 & 88 & 87 & 87 & 89 & 89 & 90 & 90 & & & \\
\hline 10 & Gloeobacter violaceus PCC 7421 & 88 & 88 & 87 & 87 & 89 & 88 & 88 & 88 & 87 & & \\
\hline 11 & Anagnostidinema pseudacutissimum CCALA 142 & 90 & 90 & 88 & 92 & 91 & 91 & 91 & 87 & 88 & 87 & \\
\hline 12 & Anagnostidinema amphibium RO-MK72 & 89 & 90 & 88 & 92 & 92 & 91 & 91 & 88 & 88 & 87 & 98 \\
\hline
\end{tabular}

gradually attenuated at the ends, sometimes bent or hooked, never calyptrate or capitate (Fig. 2O-V).

Habitat: Freshwater, benthic, usually in periphyton of stagnant waters, in greenhouses, on wet soils, etc.

Holotype: Gomont (1892), as a specimen authenticated in the Agardh Herbarium, housed in the Lund University Botanical Museum. Due to the ambiguous nature of old dried material, we here designate an epitype.

Epitype: dry material CBFS A508 is based on the strain RO-MK72.

\section{Species belonging to Anagnostidinema according to morphology}

Anagnostidinema acutissimum (KufFerATH) STRUNecký, BohunickÁ, Johansen et KomÁrek comb. nov. - Basionym: Oscillatoria acutissima Kufferath, Ann. Biol. Lac. 7: 264, 1914

Anagnostidinema carotinosum (GeITLER) comb. nov. (basionym: Oscillatoria carotinosa GeITLER, Österr. Bot. Zeitschr. 103(2-3): 342, pl 1, figs. a, b, 1956; syn: Phormidium carotinosum (GeItler) AnAgnosTIDIS et KomÁreK, Arch. Hydrobiol. Suppl./Algol. Stud. 50-53: 404, 1988; Geitlerinema carotinosum (Geitler) Anagnostidis, Plant. Syst. Evol. 164: 39, 1989)

Anagnostidinema deflexum (W. et G.S. West) comb. nov. - Basionym: Oscillatoria deflexa W. et G.S. West, Brit. Antarct. Exped. 1(7): 295, 1911

Anagnostidinema epiphloeophyticum (ANAGNostidis) comb. nov. - Basionym: Geitlerinema epiphloeophyticum Anagnostidis, Preslia 73: 364, 2001
Anagnostidinema exile (SKUJA) comb. nov. - Basionym: Oscillatoria exilis Skuja, N. Acta Reg. Soc. Sci. Upsal. Ser. 4, 18(3): 51, 1964

Anagnostidinema ionicum (SKUJA) comb. nov. - Basionym: Oscillatoria ionica Skuja, Hedwigia 77: 30, 1937

Anagnostidinema lacus-solaris (CAMPBELl et GoluBIC) comb. nov. - Basionym: Oscillatoria lacus-solaris Campbell et Golubic, Algol. Stud. 38/39: 324-325, 1985

Anagnostidinema lemmermannii (Woloszynska) comb. nov. - Basionym: Oscillatoria lemmermannii Woloszynska, Bull. Int. Acad. Sci. Cracovie, mat.-nat., Ser. B, 1911: 689, 1912

Anagnostidinema tenue (ANIsIMOVA) comb. nov. - Basionym: Oscillatoria amphibia f. tenuis Anisimova in Elenkin Monogr. Alg. Aquidulc., Pars spec. 2: 1326, 1949. = Geitlerinema tenue (ANISIMOVA) ANAGNOSTIDIS, Preslia 73: 364, 2001

The overview of the genera Geitlerinema and Anagnostidinema after revision is included in Table S2. The generic position of other Geitlerinema species (cf. KomÁreK \& ANAgnostidis 2005) must be solved by other studies, together with their morphological characterization.

\section{Discussion}

Our combined morphological and phylogenetic analyses confirmed the polyphyletic nature of the genus Geitlerinema reported previously by PERKERSON et al. 

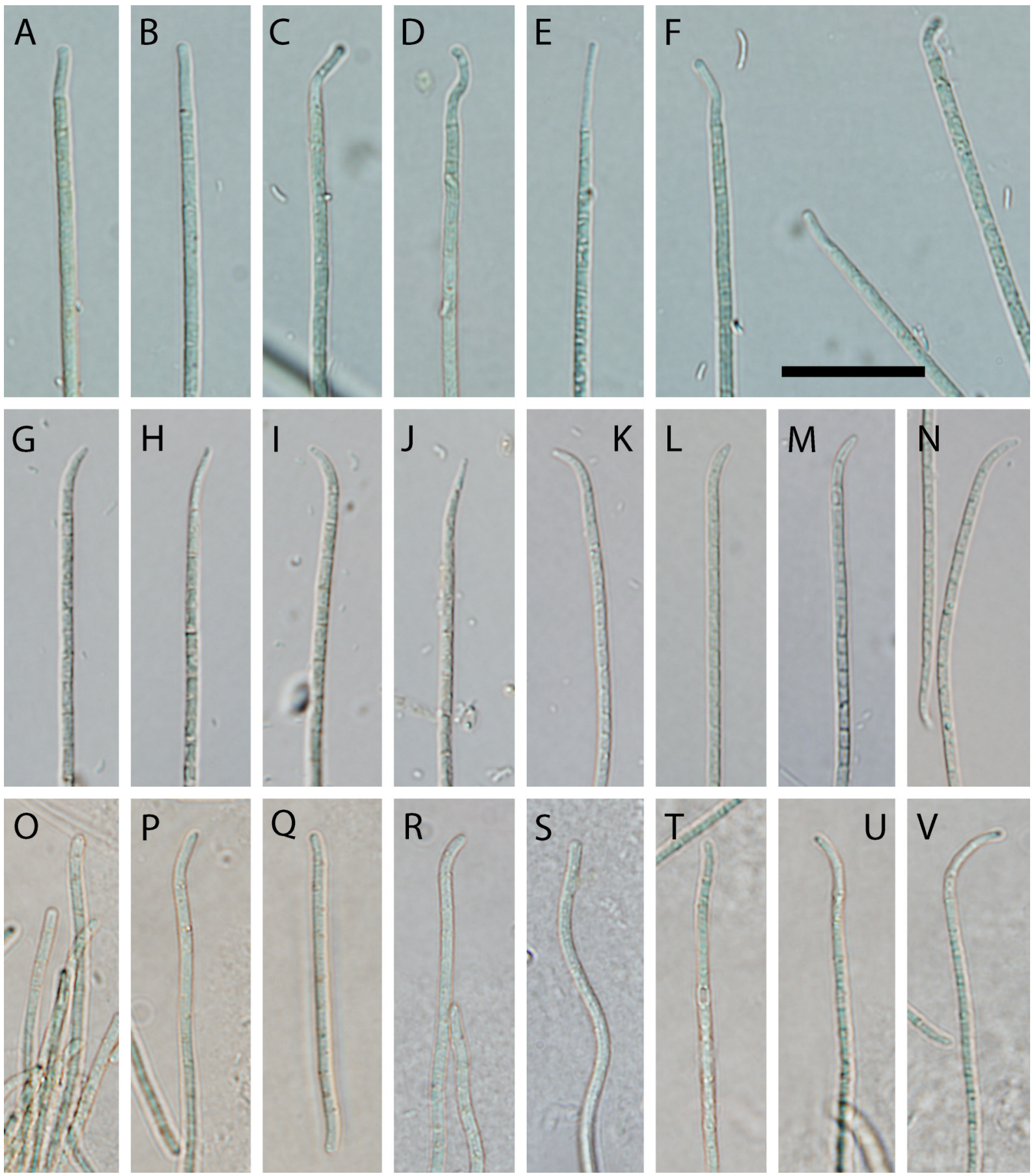

Fig. 2. Morphology of the members of the genera Geitlerinema and Anagnostidinema: (A-F) G. splendidum CCALA 1004, (G-J) A. pseudacutissimum CCALA 150, (K-N) A. pseudacutissimum CCALA 142, (O-V) A. amphibium RO-MK72. Scale bar $=20 \mu \mathrm{m}$, applies to all figures.

(2010) and HAŠLER et al. (2012). The genus Geitlerinema was validly established by ANAGNOSTIDIs (1989) with the type species designated as G. splendidum, which can be clearly characterized by the capitate, spoon-like ends of apical cells. Although the shape of the apical cells is characteristic and easily recognizable, and the taxon is widely reported, we have not found this species in any culture collection prior to reports of the three strains given here. Our three strains corresponding to $G$. splendidum fully agree with the morphological description of ANAGNOSTIDIS (1989) and with the original description of GREVILLE ex GOMONT (1892). We recommend using Geitlerinema splendidum CCALA1004, the basis of the epitype we designate here, as a morphologically confirmed reference strain. We also use the sequence of the widely cited bacterial marker, the 16S rRNA gene of the strain $G$. splendidum CCALA 1004 (KP412630), as a reference sequence of the genus Geitlerinema. At present, all strains from the genus Geitlerinema are of freshwater origin.

Other species that were recognized as Geitle- 

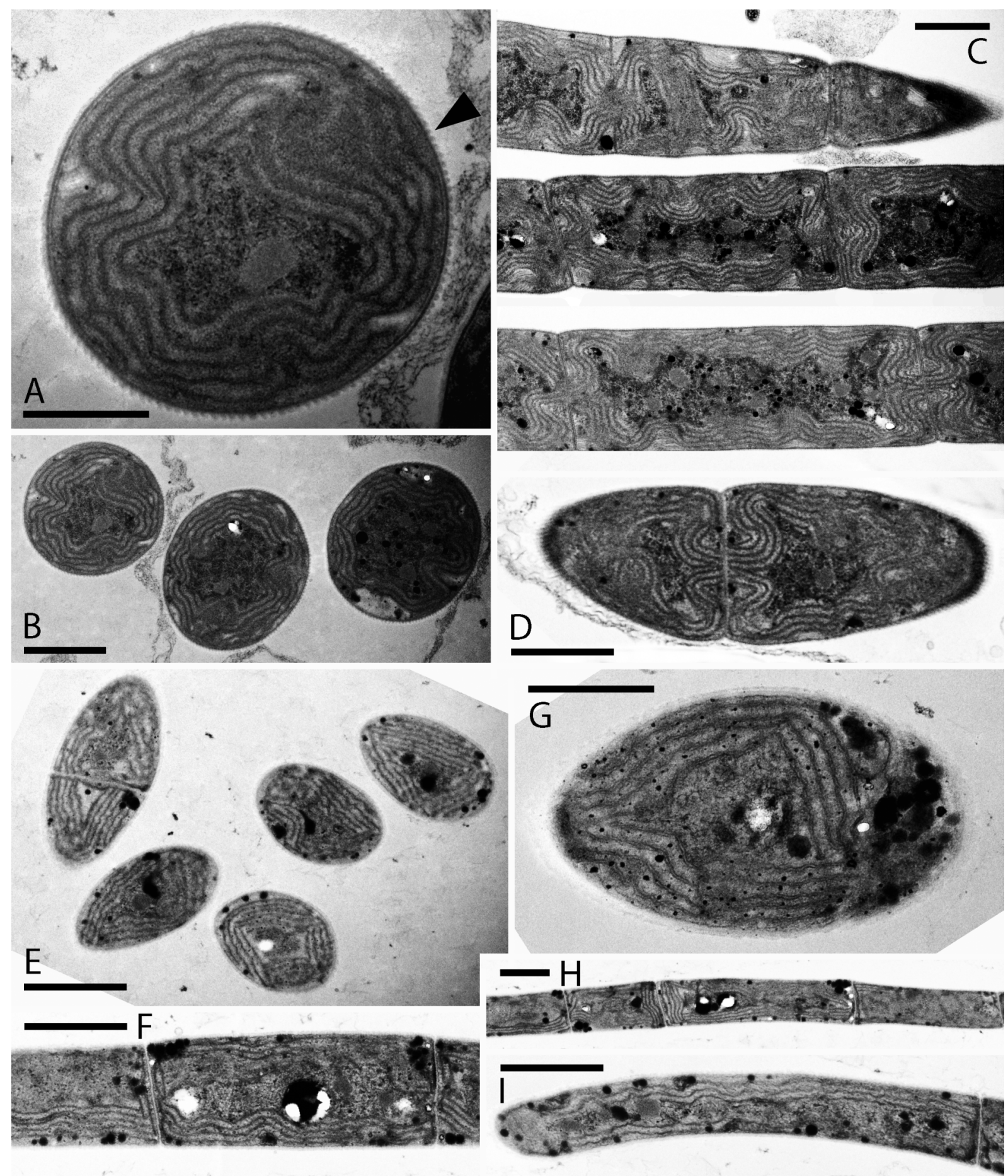

Figure 3. Ultrastructure the members of the genera Geitlerinema and Anagnostidinema examined in TEM: (A-D) G. splendidum CCALA 1004, (A, B) transversal sections of the trichome, arrow points to its the typical mucilaginous cover, (C, D) longitudinal sections; (E-I) $A$. pseudacutissimum GSE-PSE04-08G, (E, G) transversal sections of the trichome, (F-I) longitudinal sections of the trichome. Scale bar (A, G) $500 \mathrm{~nm},(\mathrm{~B}-\mathrm{D}, \mathrm{E}-\mathrm{F}, \mathrm{H}-\mathrm{I}) 1 \mu \mathrm{m}$.

rinema according to KoMÁReK \& ANAGNOSTIDIS (2005) are morphologically and presumably also phylogenetically distant from G. splendidum; thus they do not belong to the genus Geitlerinema and must be taxonomically reevaluated. We have transferred a number of non-capitate species into Anagnostidinema gen. nov. (Table S2). However, several others, e.g. G. acuiforme,
G. nematodes, or G. acuminatum probably belong in close vicinity of the genus Oxynema (CHATCHAWAN et al. 2012), whereas G. jasorvense possibly belongs in Kamptonema (Strunecky et al. 2014). The taxonomic position of these species must await definitive resolution in future studies.

In the most recent taxonomic system proposed 

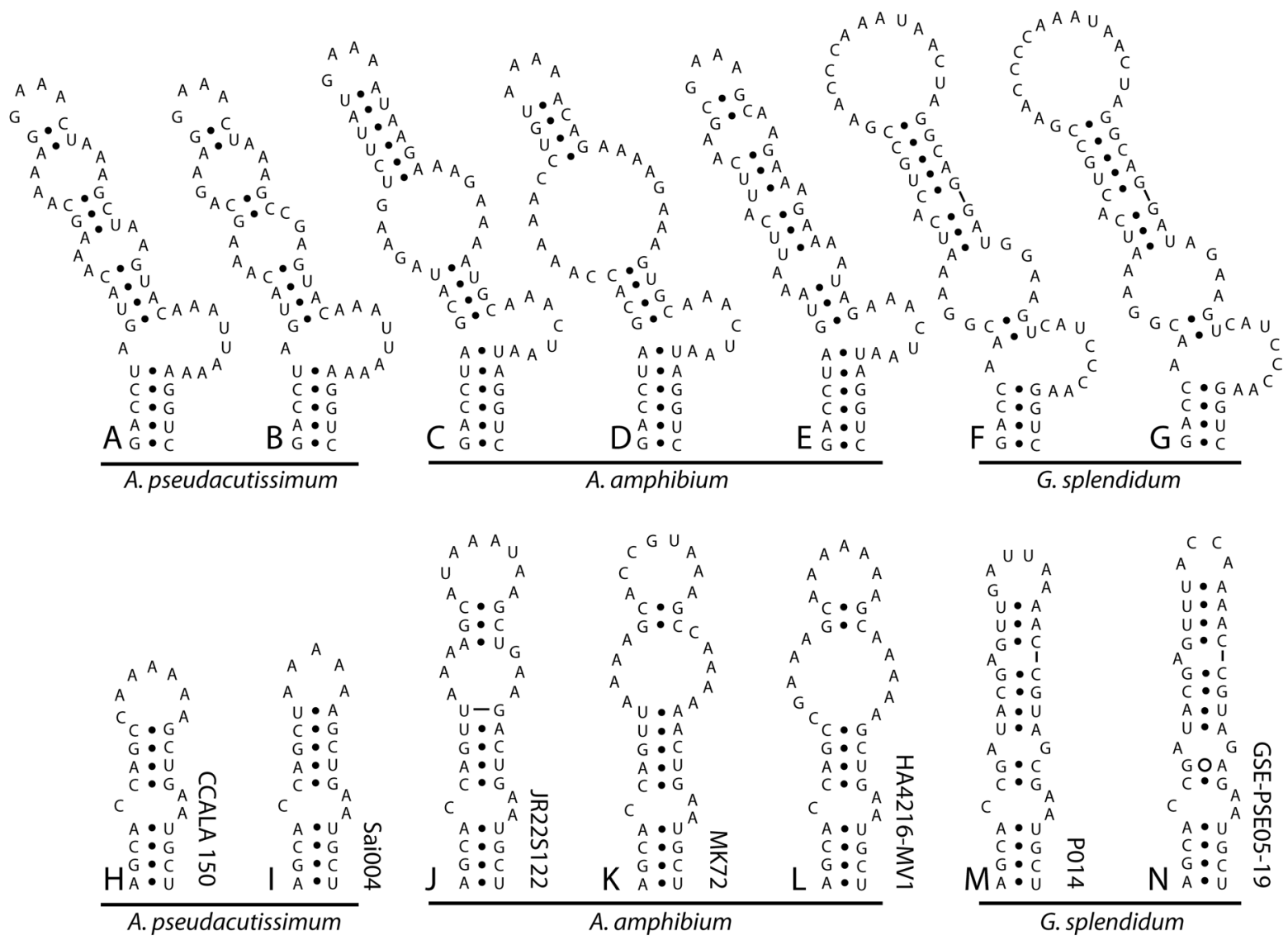

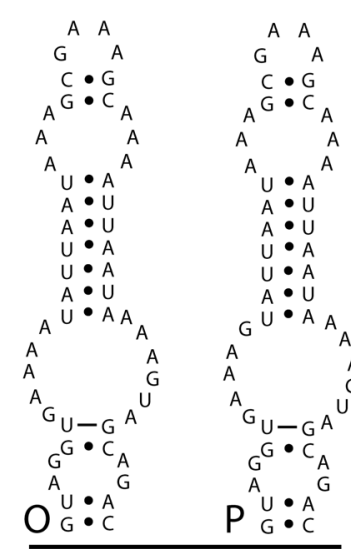

A.pseudacutissimum

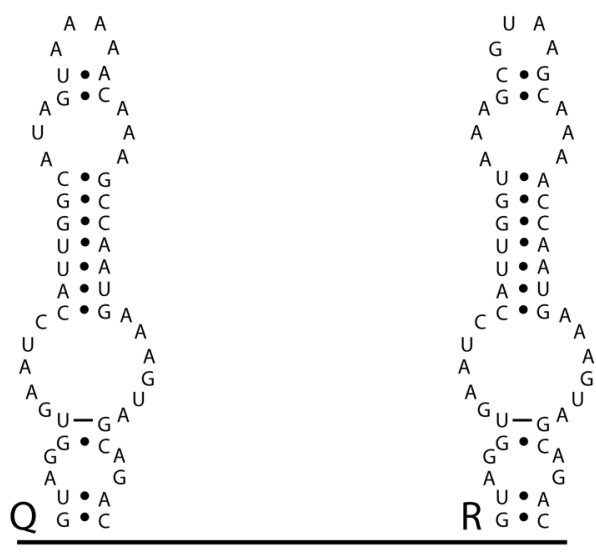

A. amphibium

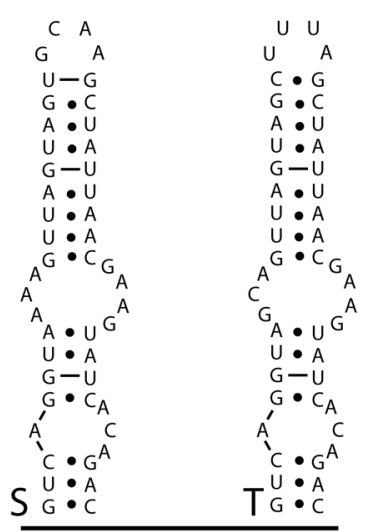

G. splendidum

Figure 4. Characterization of the secondary structures of the ITS regions in studied strains of Geitlerinema and Anagnostidinema: (A-G) D1D1' helix, (H-N) boxB helix, (O-T) V3 helix; (A-B, H-I, O-P) Anagnostidinema pseudacutissimum, (C-E, J-L, Q-R) A. amphibium, (F-G, M-N, S-T) G. splendidum (GSE-PSE05-19 = CCALA 1004).

by KomÁreK et al. (2014), Geitlerinema was assigned to the Coleofasciculaceae. However, in our study the phylogenetic position of G. splendidum (and therefore of the genus Geitlerinema after revision) is sister to the cellulose and cylindrospermopsin producing clade Gomontiellaceae (cf. Fig. 1; BoHUnicKÁ et al. 2015), which is rather curious. Species of the family Gomontiellaceae have distinctively constricted cross walls and they possess special morphology (trichomes not circular in cross-section) among the non-heterocytous, filamentous cyanobacteria (BOHUNICKÁ et al. 2015). Geitlerinema will likely need to be reassigned to a different family in the future, as its placement based on our analysis is currently ambiguous.

Anagnostidinema forms a new very isolated clade of cyanobacteria and their detailed phylogenetic relationships to other filamentous cyanobacteria could be better resolved using a multiple loci or whole genome phylogenetic approach in the future. Yet, the creation of the new genus Anagnostidinema for freshwater 
representatives with more or less unique morphology is supported by the abundance of accessible strains (Table 1). The high number of sequences based on either cultured or uncultured material that are deposited in GenBank suggests wider distribution of the genus Anagnostidinema than that of Geitlerinema sensu stricto.

Our phylogenetic analysis based on the $16 \mathrm{~S}$ rRNA gene clearly separated also other highly motile species with similar morphologies that were previously included in the genus Geitlerinema and originated from a marine environment. These species did not possess the rounded-capitate apical cells and were phylogenetically distant from Anagnostidinema, therefore they must be separated into other genera in future studies. This is true in the case of the marine strain Geitlerinema sp. PCC 7105, recognized as a reference strain for the genus Geitlerinema according to Bergey's Manual (CAstenholz et al. 2001). In Bergey's Manual the concept of the genus Geitlerinema is wider than that given in the original description (ANAGNOSTIDIS 1989). It includes filamentous cyanobacteria with straight to slightly coiled cylindrical trichomes without necridia, less than 5-6 $\mu \mathrm{m}$ in diameter with active (gliding) motility accompanied by trichome rotation. Cells are longer than broad or isodiametric, dividing by binary fission; constrictions between adjacent cells are absent or very shallow. Apical cells are rounded, conical or distinctly pointed, tapered, and often bent (CASTENHOLZ et al. 2001). This concept of the genus Geitlerinema has led subsequent workers to identify many other marine strains as Geitlerinema based on BLAST searches or sequence similarity, and such strains have been reported from tropical oceans in coral reefs or associated with stromatolites (RICHERT et al. 2006; MyERS et al. 2007). Our study clearly demonstrates that the marine types recognized as Geitlerinema are phylogenetically distant from freshwater Geitlerinema (Fig. 1). These marine "Geitlerinema" have a basal paraphyletic relationship to all Oscillatoriophycidae and Nostocophycidae according to the 30-loci phylogeny in KOMÁREK et al. (2014), and likely represent a separate, yet undescribed order of cyanobacteria.

\section{ACKNOWLEDGEMEnTs}

The study was supported by the Czech Grant Agency GACR 206/07/0115 and No CSF 15-00113S and CSF 15-11912S and CSF13-13368S, by the Ministry of Education, Youth and Sports of the Czech Republic - projects "CENAKVA" (No. CZ.1.05/2.1.00/01.0024) and "CENAKVA II" (No. LO1205 under the NPU I program), and by long-term research development project no. RVO67985939. We thank CCALA Culture Collection of Autotrophic Organisms in Třeboň for providing their Geitlerinema strains

\section{References}

Anagnostidis, K. (1989): Geitlerinema, a new genus of Os- cillatorialean cyanophytes. - Plant. Syst. Evol. 164: $33-46$.

Anagnostidis, K. (2001): Nomenclatural changes in cyanoprokaryotic order Oscillatoriales. - Preslia 73: 359-75.

AnAgnostidis, K. \& KomáreK, J. (1988): Modern approach to the classification system of cyanophytes. - Arch. Hydrobiol. 3: 327-472.

Bittencourt-Oliveira, M.D.; Moura, A.D.; de Oliveira, M.C. \& Massola, N.S. (2009): Geitlerinema species (Oscillatoriales, Cyanobacteria) revealed by cellular morphology, ultrastructure, and DNA sequencing. J. Phycol. 45: 716-25.

Bohunická, M.; Mareš, J.; Hrouzek, P.; Urajová, P.; Lukeš, M.; Šmarda, J.; Komárek, J.; Gaysina, L.A. \& StruNECKÝ, O. (2015): A combined morphological, ultrastructural, molecular, and biochemical study of the peculiar family Gomontiellaceae (Oscillatoriales) reveals a new cylindrospermopsin-producing clade of cyanobacteria. - J. Phycol. 51: 1040-54.

Campbell, S.E. \& Golubić, S. (1985): Benthic cyanophytes (cyanobacteria) of Solar Lake (Sinai). - Arch. Hydrobiol. 38/39: 311-29.

Carmichael, W.W. (1986): Isolation, culture, and toxicity testing of toxic freshwater cyanobacteria (blue-green algae). - In: Shilov, V. (eds.): Fundamental research in homogenous catalysis, Gordon \& Breach, New York, - pp. 1249-62.

Castenholz, R.W.; RippKa, R. \& Herdman, M. (2001): Form-genus IV. Geitlerinema stat. nov. - In: Boone, D. R.; Castenholz, R. W. \& Garrity, G. M. (eds.): Bergey's manual of systematic bacteriology, $-\mathrm{pp}$. 722, International Society for Microbial Ecology.

Chatchawan, T.; KomáreK, J.; Strunecký, O.; Šmarda, J. \& Peerapornpisal, Y. (2012): Oxynema, a new genus separated from the genus Phormidium (Cyanophyta). - Cryptogamie Algol. 33: 41-59.

ELENKIN, A. A. (1949): Monographia algarum cyanophycearum aquidulcium et terrestrium in finibus URSS inventarum [Sinezelenye vodorosli SSSR]. - Pars spec. 2, Izd. AN SSSR, Moskva-Leningrad, pp 1908.

GeItLer, L. (1956): Oscillatoria carotinosa n. sp. and $O$. pseudoacutissima n. sp., zwei Arten mit lokalisierter Karotinoidbildung. - Osterr. Bot. Z. 103: 342-45.

Gomont, M. (1892): Monographie des Oscillariées (Nostocacées Homocystées). Deuxième partie. - Lyngbyées. - Annales des Sciences Naturelles, - pp. 302, Botanique, Masson.

Hall, T. A. (1999): BioEdit: a user-friendly biological sequence alignment editor and analysis program for Windows 95//98//NT. - Nucleic Acids Symp. Ser. 41: 95-98.

HAŠLER, P.; DVoŘÁK, P.; JohANSEn, J. R.; Kitner, M.; ONDŘEJ, V. \& PoulíčKovÁ, A. (2012): Morphological and molecular study of epipelic filamentous genera Phormidium, Microcoleus and Geitlerinema (Oscillatoriales, Cyanophyta/Cyanobacteria). - Fottea 12: 341-56.

Kатон, K. \& Tон, H. (2010): Parallelization of the MAFFT multiple sequence alignment program. - Bioinf. 26: 1899-900.

KomÁReK, J. \& AnAgnostidis, K. (2005): Cyanoprokaryota -2. Teil/ 2nd Part: Oscillatoriales. - Elsevier/Spektrum, - pp 759, Heidelberg.

KomÁrek, J.; Kaštovský, J.; Mareš, J. \& Johansen, J. R. (2014): Taxonomic classification of cyanoprokaryo- 
tes (cyanobacterial genera) 2014, using a polyphasic approach. - Preslia 86: 295-335.

KufFerath, H. (1914): Contribution à l'étude de la flore algologique du Luxembourg meridionale. Chlorophycees (exclus. Desmidiacées), Flagellates et Cyanophycées. - Ann. Biol. Lac. 2: 231-71.

Mareš, J.; HrouZek, P.; Kaña, R.; Ventura, S.; StruneckÝ, O. \& KomÁreK, J. (2013): The primitive thylakoidless cyanobacterium Gloeobacter is a common rockdwelling organism. - PloS one 8: e66323.

Margheri, M.C.; Piccardi, R.; Ventura, S.; Viti, C. \& GiovannetTI, L. (2003): Genotypic Diversity of Oscillatoriacean strains belonging to the genera Geitlerinema and Spirulina determined by 16S rDNA restriction analysis. - Curr. Microbiol. 46: 0359-64.

Myers, J.L.; Sekar, R. \& Richardson, L.L. (2007): Molecular detection and ecological significance of the cyanobacterial genera Geitlerinema and Leptolyngbya in black band disease of corals. - Appl. Environ. Microb. 73: 5173-82.

Nübel, U.; Garcia-Pichel, F. \& Muyzer, G. (1997): PCR primers to amplify $16 \mathrm{~S}$ rRNA genes from cyanobacteria. - Appl. Environ. Microb. 63: 3327-32.

Perkerson, R.B.; Johansen, J.R.; KováčiK, L.; Brand, J.; KaštovskÝ, J. \& Casamatta, D.A. (2011): A unique Pseudanabaenalean (Cyanobacteria) genus Nodosilinea gen. nov. based on morphological and molecular data. - J. Phycol. 47: 1397-412.

Perkerson, R.B.; Perkerson, E.A. \& Casamatta, D.A. (2010): Phylogenetic examination of the cyanobacterial genera Geitlerinema and Limnothrix (Pseudanabaenaceae) using 16S rDNA gene sequence data. - Algol. Stud. 134: 1-16.

Richert, L.; Golubić, S.; Le Guédès, R.; Hervé, A. \& Payri, C. (2006): Cyanobacterial populations that build 'kopara' microbial mats in Rangiroa, Tuamotu Archipelago, French Polynesia. - Eur. J. Phycol. 41: 259-79.

Rippka, R.; Deruelles, J.; Waterbury, J.B.; Herdman, M. \& StANIER, R.Y. (1979): Generic assignments, strain histories and properties of pure cultures of cyanobacteria. - J. Gen. Microbiol. 111: 1-61.

Romo, S.; Miracle, M.R. \& Hernandez-Marine, M. (1993): Geitlerinema amphibium (Ag. Ex Gom.) Anagnostidis (Cyanophyceae) - Morphology, Ultrastructure and Ecology. - Arch. Hydrobiol. 69: 11-27.

Ronquist, F. \& Huelsenbeck, J. (2003): MrBayes 3: Bayesian phylogenetic inference under mixed models. Bioinf. 19: 1572-74.

SkuJA, H. (1964): Grundzüge der Algenflora und Algenvegetation der Fjeldgegenden um Abisko in SchwedischLappland. - Nova Acta Reg. Soc. Sci. Upsal. Ser. IV 3: $465 \mathrm{pp}$.

SkuJA, H. (1937): Süsswasseralgen aus Griechenland und Kleinasien. - Hedwigia 77: 15-70.

StAMATAKIS, A. (2006): RAxML-VI-HPC: maximum likelihood-based phylogenetic analyses with thousands of taxa and mixed models. - Bioinf. 22: 2688-90.

Stringfellow, E.A.; Perkerson, R. \& Casamatta, D. (2007): An exploration of the genus Geitlerinema (Pseudanabaenaceae) using a combined molecular and morphological approach. - J. Phycol. 43: 53-53.

Strunecký, O.; KomáreK, J. \& Šmarda, J. (2014): Kamptonema (Microcoleaceae, Cyanobacteria), a new genus derived from the polyphyletic Phormidium on the basis of combined molecular and cytomorphological markers. - Preslia 86: 193-208.

Tamura, K.; Peterson, D.; Peterson, N.; Stecher, G.; Nei, M. \& Kumar, S. (2011): MEGA5: Molecular Evolutionary Genetics Analysis Using Maximum Likelihood, Evolutionary Distance, and Maximum Parsimony Methods. - Mol. Biol. Evol. 28: 2731-39.

West, G.S. (1909a): The algae of the Birket Qarun, Egypt. Jour. Bot. 67: 237-44.

West, W. \& West, G.S. (1911): Freshwater Algae in British Antarctic Expedition 1907-09. - Biology, part 7, 1: 263-298.

Wilmotte, A.; Van der Auwera, G. \& De Wachter, R. (1993): Structure of the $16 \mathrm{~S}$ ribosomal RNA of the thermophilic cyanobacterium Chlorogloeopsis HTF ('Mastigocladus laminosus HTF') strain PCC7518, and phylogenetic analysis. - FEBS Lett. 317: 96100.

WoloszynSKA, J. (1912): O glonach planktonozvych niektôrych jezior jazuanskich, z irwzglçdnieniem glonôzu Sazvy. Das phytoplankton einiger javanischer seen, mit berücksichtigung des Sawa-planktons. Bull. Int. Acad. Sci. Cracovie, Cl. Sci. Math., Ser. B: Sci. Nat. 1912: 649-709.

ZUKER, M. (2003): Mfold web server for nucleic acid folding and hybridization prediction. - Nucleic Acids Res. 31: 3406-15.

Supplementary material

the following supplementary material is available for this article:

Table S1. Sequence lengths for the recognized domains of the 23S-16S ITS region.

Table S2. List of traditional Geitlerinema species according their former morphologic designation.

This material is available as part of the online article (http:// fottea.czechphycology.cz/contents)

(C) Czech Phycological Society (2017)

Received September 15, 2016

Accepted Novemember 1, 2016 